\section{Molecular Diagnostics: Another Battle Brewing}

Well, the Centers for Medicare \& Medicaid Services (CMS) has a new policy in development (https://www.cms.gov/Newsroom/MediaReleaseDatabase/Press-releases/ 2017-Press-releases-items/2017-11-30-2.html) that is bound to make some feathers fly. The policy would limit coverage for next-generation sequencing (NGS) tests to those that are FDA-approved. Frankly, that list of tests is pretty short right now, involving only a few companies. But it includes some major powerhouses, such as FoundationOne, which now has approval for its CDx diagnostic test.

I've been pretty public about my endorsement of FDA approval of diagnostics. ${ }^{1}$ Not everyone agrees with this position, though, especially pathology groups who, in their defense, have made big investments in setting up Clinical Laboratory Improvement Amendments (CLIA)-based environments for testing, but lack the infrastructure or resources to seek FDA approval.

As I've said before, the FDA has always had authority over approvals for diagnostics, although it really hasn't exerted its strength. Maybe this policy is the way to do it. After all, if the business model for reimbursement involves FDA approval, then anyone developing a new test better be thinking about this from the start. At the same time, validating a biomarker for clinical utility is a cumbersome and expensive process. Small companies with innovative technologies would need a lot of venture capital to get this done and many would fail. It's a tough world out there.

And what about other biomarker tests? NGS is only part of our diagnostic portfolio. As an example, immunohistochemistry is a mainstay in diagnostic pathology and, yes, we even have drugs like pembrolizumab that are indicated for protein-based biomarkers such as microsatellite instability. That's not an FDA-approved test. Is CMS going there too?

In some ways, I feel that the cart may be going before the horse. The FDA has never provided a clear vision about how it would regulate diagnosticst or indicated that it even has the capacity to do so. And what would the strategy be for legacy diagnostics already in common clinical use?

Rather than just taking a bold move going forward to tie Medicare coverage to FDA approval, I think the agency might want to step back and think this through. Focusing again on NGS would leave some patients out. My patients with fine-needle aspirates as their only diagnostic sample usually have insufficient material to sequence. We can often overcome this problem by analyzing cell-free DNA, but these aren't FDA-approved tests. What's the workaround for that?

I do think we have to be mindful that there are real patients at the center of this. I applaud those companies and institutions that have navigated the difficult path to approval for testing. And I do think, in concept, that FDA regulation could be a very good thing.

But until we've sorted out all the untended consequences, we might want to tread carefully. Precision medicine is here to stay and, in some cases, is transformative. We need to be sure we aren't enforcing rules that could limit access to better care.

\section{Reference}

1. Tempero M. Turf war over diagnostic testing. J Natl Compr Canc Netw 2015;13:375.

What do you think? Please e-mail correspondence (include contact information) to JNCCN@nccn.org or log into www.editiorialmanager.com/JNCCN to submit a Letter to the Editor.

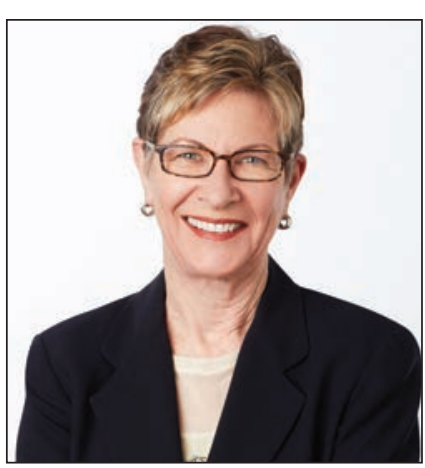

Margaret Tempero, MD

Margaret Tempero, MD, is a Professor of Medicine and Director of the UCSF Pancreas Center and editor-in-chief of JNCCN. Her research career has focused on pancreatic ductal adenocarcinoma, especially in the area of investigational therapeutics. Dr. Tempero has served on the ASCO Board of Directors and as ASCO President. She currently serves on the ASCO Conquer Cancer Foundation Board. She codirected the AACR/ASCO Methods in Clinical Cancer Research and taught this course and similar courses in Europe and Australia. She was founding Chair of the $\mathrm{NCl}$ Clinical Oncology Study Section and served as a member and Chair of the NCl Board of Scientific Counselors Subcommittee A. She is a member of the Scientific Steering Committee and Chair of the Clinical and Translational Study Section for the Cancer Prevention \& Research Institute of Texas. She is or has been on the Scientific Advisory Boards of the Lustgarten Foundation, the Pancreatic Cancer Action Network, the V Foundation, The Alberta Canada Cancer Board, and the EORTC. She served as a member of the Oncology Drug Advisory Committee for the FDA. She has served as Deputy Director and Interim Director for the UNMC Eppley Cancer Center. She is Chief Emeritus of the Division of Medical Oncology at UCSF and served as the founding Deputy Director and Director of Research Programs at the UCSF Helen Diller Family Comprehensive Cancer Center.

doi: 10.6004/jnccn.2018.0015

The ideas and viewpoints expressed in this editorial are those of the author and do not necessarily represent any policy, position, or program of NCCN. 